IRA-International Journal of Management \& Social Sciences

ISSN 2455-2267; Vol.04, Issue 03 (2016)

Pg. no. 612-618

Institute of Research Advances

http://research-advances.org/index.php/RAJMSS

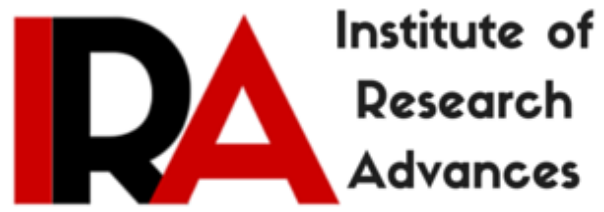

\title{
MSME's Sector in India: Challenges and Opportunities
}

\author{
${ }^{1}$ E. Upendar \& ${ }^{2}$ Dr. K. Ramulu \\ ${ }^{1}$ Research Scholar, School of Management Studies, \\ University of Hyderabad, India. \\ ${ }^{2}$ Assistant Professor, School of Management Studies, \\ University of Hyderabad, India.
}

Type of Review: Peer Reviewed.

DOI: http://dx.doi.org/10.21013/jmss.v4.n3.p11

\section{How to cite this paper:}

Upendar, E., \& Ramulu, K. (2016). MSME's Sector in India: Challenges and Opportunities. IRA-International Journal of Management \& Social Sciences (ISSN 24552267), 4(3), 612-618. doi:http://dx.doi.org/10.21013/jmss.v4.n3.p11

(C) Institute of Research Advances

\section{(c) ) EY-No}

This work is licensed under a Creative Commons Attribution-Non Commercial 4.0 International License subject to proper citation to the publication source of the work.

Disclaimer: The scholarly papers as reviewed and published by the Institute of Research Advances (IRA) are the views and opinions of their respective authors and are not the views or opinions of the IRA. The IRA disclaims of any harm or loss caused due to the published content to any party. 


\section{ABSTRACT}

Micro Small and Medium Enterprises include Khadi, Village and Rural Enterprise. Today Millions of people depending upon MSMEs sector. Indian MSMEs are contributing regarding $45 \%$ manufacturing output and $40 \%$ exports. Every year 8-9\% of GDP contributing to developing the nation.This sector is providing employment second largest after agriculture. The main advantage of this sector is employment potential low capital. MSMEs sector contributing develop the country but every day facing a number of challenges like the High cost of Raw materials, collateral requirements, Competition from domestic and foreign markets, Increased fuel prices, lack of credit facilities from financial institutions, etc. Due to the financing problems, every day 79 MSMEs are falling in sickness. The government took many initiatives for this sector but still problems persist. There are many opportunities in this sector for budding entrepreneurship but due to the many challenges the MSMEs sector is still unable to survive.The study is based on secondary data only. Every year this sector is worldwide generating 3, 000 employment opportunities for the people. The MSMEs sector is playing important role in poverty reduction and regional imbalances. Still today the Government of India took there are many initiatives to develop this sector but still the problems are encountering this sector.

KEYWORDS: MSMEs, India, GDP, Financing Problems, Government, Employment, Poverty Reduction.

\section{Introduction:}

\section{Micro Small and Medium Enterprises (MSMEs):}

Micro Small and Medium Enterprises are recognised as the engine of growth all over the world. In India, MSMEs are more than $80 \%$ of the total number of enterprises. MSMEs sector includes 2.2 million women - led enterprises (7.4\%) and 15.4 million Rural Enterprises (51.8\%). The Micro, Small and Medium Enterprise sector is crucial to India's economy. There are 30 million enterprises in various industries, employing 69 million people. Together, these account for $45 \%$ of the industrial output and $40 \%$ of the exports. The President under Notification dated $9^{\text {th }}$ May 2007 has amended the Government of India (Allocation of Business) Rules, 1961. Under this amendment, Ministry of Agro and Rural Industries and Ministry of Small Scale Industries have been merged into a single Ministry, namely, "MINISTRY OF MICRO, SMALL AND MEDIUM ENTERPRISES (SUKSHMA LAGHU AUR MADHYAM UDYAM MANTRALAYA)"

\section{Definition of MSMEs According to the MSMEs Act 2006.}

\begin{tabular}{|l||l||l|}
\hline $\begin{array}{c}\text { Manufacturing Sector } \\
\text { (Investment in Plant } \\
\text { \&Machinery) }\end{array}$ & Enterprises & \multicolumn{1}{c|}{$\begin{array}{c}\text { Service Sector } \\
\text { (Investment in Equipment) }\end{array}$} \\
\hline $\begin{array}{l}\text { Doesn't exceed Rs.25 lakh } \\
\text { rupees }\end{array}$ & MICRO & Doesn't exceed 10 lakh rupees \\
\hline $\begin{array}{l}\text { More than 25 lakh rupees but } \\
\text { doesn't exceed five crore rupees }\end{array}$ & SMALL & $\begin{array}{l}\text { More than 10 lakh rupees but doesn't } \\
\text { exceed two crore rupees. }\end{array}$ \\
\hline $\begin{array}{l}\text { More than five crore rupees but } \\
\text { doesn't exceed ten crore rupees }\end{array}$ & MEDIUM & $\begin{array}{l}\text { More than 10 lakh rupees but doesn't } \\
\text { exceed two crore rupees. }\end{array}$ \\
\hline
\end{tabular}

Source: Ministry of Micro, Small and Medium Enterprises in India. 
Broad Classification of MSMEs in India:

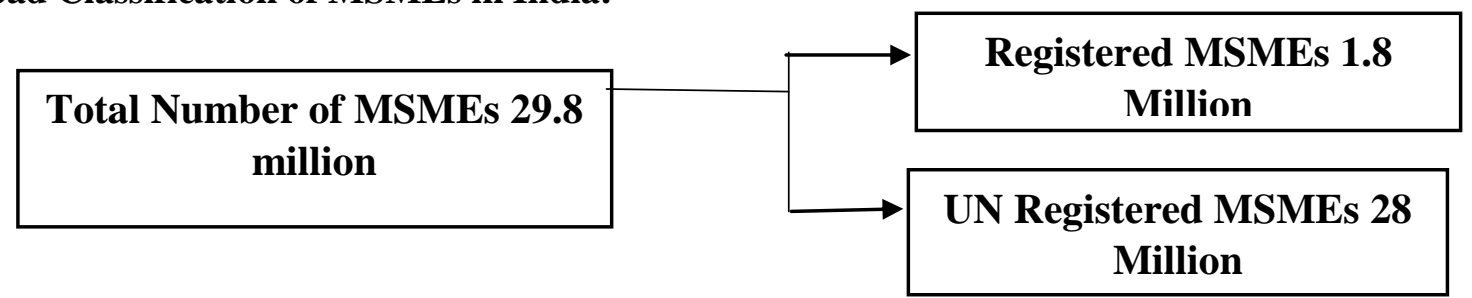

Source: MSMEs Census (2012)

Economic Contribution of MSMEs in India:

\begin{tabular}{|l|l||l||}
\hline S.no & Share of & Value \\
\hline \hline $\mathbf{1}$ & Industrial Units & $95 \%$ \\
\hline \hline $\mathbf{2}$ & Industrial Output & $45 \%$ \\
\hline \hline $\mathbf{3}$ & Exports (In value) & $40 \%$ \\
\hline \hline $\mathbf{4}$ & Gross Domestic Product(GDP) & $8 \%$ \\
\hline \hline $\mathbf{5}$ & Employment(In Million) & 69 \\
\hline
\end{tabular}

Source: MSMEs Annual Report (2009-10)

\section{Review of Literature:}

A brief review of literature relating to the objectives of the present study. The review of literature is as follows:

- DR. A. Shiralashetti: Author discussed Indian MSMEs have remarkable progress in various enterprises manufacturing like engineering design, food processing, pharmaceutical, textile garments, retail and agro service sector. The study is based on both primary and secondary data. The main objectives of the study to examine the growth and performance of MSMEs analysed the problems of MSMEs. The Problems of MSMEs are low-quality inputs, low production capacity, transportation problems and High competition. The Conclusion is that MSMEs need to be educated and informed of the latest developments.

- Prime Minister Task Force (2010): The Indian Prime Minister appointed a task force for study the problems relating to MSMEs in India. The study is depth analysis of the main issues, six subgroups such as credit, marketing, labour, exit policy, infrastructure and taxation. The issues related to Jammu and Kashmir all the North Eastern Region. The study revealed that many MSMEs are facing problems recommended to Government and Financial Institutions assist to MSMEs which is help to survival for MSMEs in India

- Dr Ashok Kumar Panigrahi (2012): Author Discussed risk management in MSMEs risk management is less developed within MSMEs sector. The study needs to improve right planning system of MSMEs. Discussed role and Important of MSMEs sector and Issues regarding 
MSMEs sector like Marketing, Technology, Sickness, Infrastructure and Rating Problems. The author used only secondary data in this paper and issues regarding bank lending to MSMEs.

- Dr.Sultan Singh Jaswal (2012): Author discussed MSMEs are the playing an important role in Economic and Social development of the country, and often acting as a nursery of entrepreneurship. The study is based on secondary data. The objectives of the paper study the performance and growth of MSMES and analyse the problems of MSMEs. The problems discussed high cost of credit, collateral requirements, high cost of raw materials, problems of storage, packing, lack of access global market, etc.,

- Nishanth. P and Dr Zakkariya K.A (2014): Discussion about MSMEs the problems may differ from region to region, between enterprises. The paper identified various barriers faced by the units in raising finance and also try to identify the various source of finance for MSMEs. The study is based on primary data collected from 200 MSMEs owners in Kozhikode District Kerala. They classified into categories such as financing problems, operational problems, administrative problems sales and debtor's problems of MSMEs. They found that MSMEs owners unaware of schemes for MSMEs.

- Prof M. Chandraiahand R.Vani (2014): Authors discussed MSMEs includes Khadi and Village/Rural Enterprise. The main objective of the study is to understand the role and performance of MSMEs and to explore the problems faced by the MSMEs. The study is based on secondary data. The MSMEs are facing many challenges which are an obstacle to the survival of MSMEs.The conclusion is author raised all problems relating to the MSMEs like financing, marketing technology which is affected for their survivals.

\section{Objectives of the Study:}

The Study objectives are:

1) To understand the concept of MSMEs.

2) To Study the Challenges facing by the MSMEs.

3) To Study the Opportunities of MSMEs.

\section{Research Methodology:}

This study is based on the secondary sources only. The secondary data collected from the relevant publications of Ministry of Micro Small and Medium Enterprises (MSMEs) India, different Articles and books, etc.,

\section{Micro Small and Medium Enterprises (MSME's): Challenges and Opportunities}

\section{Micro Small and Medium Enterprises (MSMEs) Challenges:}

Micro Small and Medium Enterprises facing many problems in their day - to - day operations. They found it difficult to sell their products, and they cannot spend on Advertising, Marketing, and Research, etc. They are also facing stiff competition from large and other countries which is exported their products into our country like China, Thailand, Germany. Financial Institutions have limited Exposure on MSMEs. There are multiple options for MSMEs sector get assistance, but they are unable to survival. They are selling their products immediate because of weak bargaining power and need quick money. MSMEs are unable to get required support from the concern Govt, Financial Institutions, Banks. The challenges are

Access to finance

$>$ Collateral Requirements

$>$ Access to Infrastructure

$>$ Facing stiff competition from Large firms

$>$ They cannot spend on Advertising, Sales, Promotion, Marketing, and Research 
$>$ Marketing of their products

$>$ Identification of new markets

$>$ Ineffective Marketing Strategy

$>$ Don't have own marketing networks

$>$ Limited access to Equity capital

$>$ High Cost of Raw Materials

$>$ Problems of Storage, Designing, Packing

$>$ Lack of Access to Global Markets

$>$ MSMEs are difficult in recruiting motivated and technical personnel

$>$ Lack of latest Technology

$>$ Tough competition from large firms

$>$ MSMEs are difficult to compete with another country Imported Goods

$>$ Low production capacity

$>$ Non - availability of highly skilled labour

$>$ Low Production Capacity and

$>$ Lack of Training.

MSMEs Finance Demand Flow Chart:

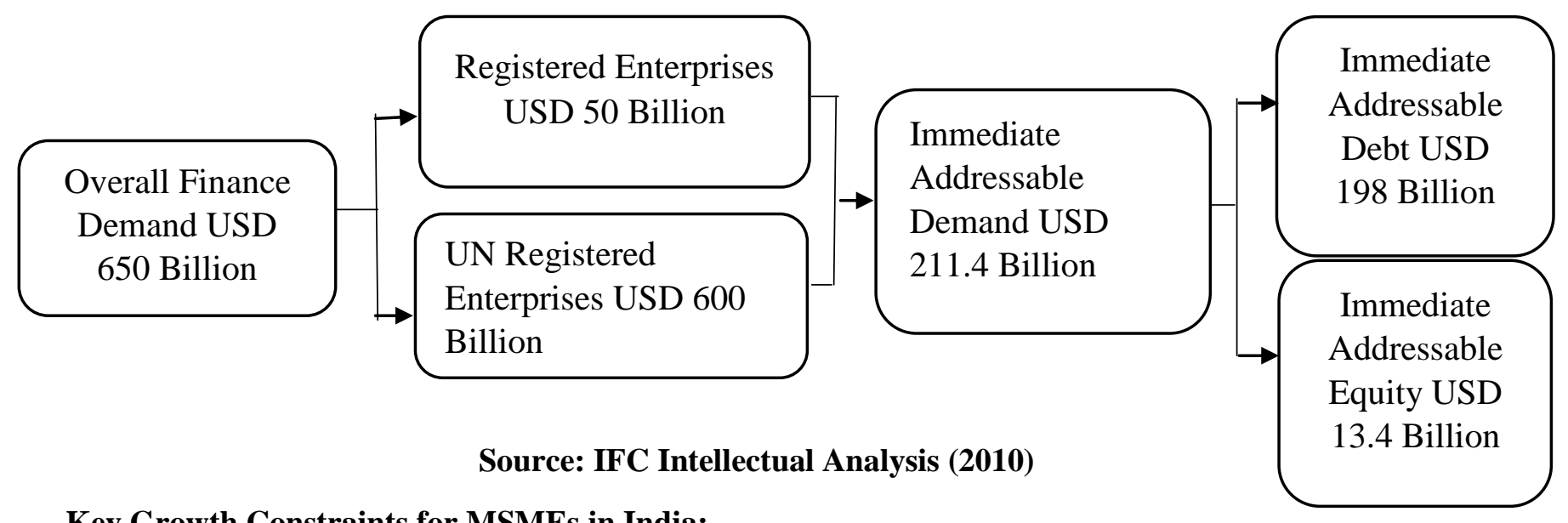

Key Growth Constraints for MSMEs in India:

\begin{tabular}{|c|l|l|}
\hline S.no & Key Growth Constraints & $\begin{array}{l}\text { In } \\
\text { Percentage }\end{array}$ \\
\hline 1. & Inadequate market Linkage & $32 \%$ \\
\hline 2 & Lack of Infrastructure & $29 \%$ \\
\hline 3. & Inadequate Finance & $28 \%$ \\
\hline 4. & $\begin{array}{l}\text { Lack of Managerial } \\
\text { Competence }\end{array}$ & $24 \%$ \\
\hline 5. & Obsolete Technology & $22 \%$ \\
\hline
\end{tabular}

Source: Report of Working Group on Rehabilitation of Sick MSMEs, Reserve Bank of India. 


\section{Micro Small and Medium Enterprises (MSMEs): Opportunities}

Nowadays many people depend on upon the MSMEs sector this sector is self-employment sector for people most of the MSMEs are from rural areas every year MSMEs sector generating 3,000 employment for the people. The MSMEs sector forever Classic.Many problems are encountering the MSMEs but still this sector is growing continuously. The opportunities of MSMEs are:

$\checkmark \quad$ Ideal Platform for entrepreneurs to produce more products

$\checkmark$ Strong Growth Potential

$\checkmark$ Low Investment Requirements

$\checkmark$ Operational Flexibility

$\checkmark$ High contribution for the domestic market

$\checkmark$ Technology oriented Enterprises

$\checkmark$ Exporting products from country

$\checkmark$ Raising Domestic Sales

$\checkmark$ Increasing National GDP

$\checkmark$ Vibrant Domestic Demand

$\checkmark$ Helps to Emerging Economy and

$\checkmark$ MSMEs are expected to become one of the fastest growing sectors in India

\section{Conclusion:}

Before formed MSMEs, we called Small Scale Industries (SSIs) and Small and Medium Enterprises (SMEs), but small is beautiful. The Indian government merged Ministry of SSI, Agro, Rural Industries into one Ministry called Micro Small and Medium Enterprises (MSMEs). The government adopted a simple structure for MSMEs to enhance and complete MESMs. There are many schemes and sources for MSMEs but still Problems persist. There are many commissions' studies to solve the problems which are encountering to develop MSMEs in India. Due to the financing problems, every day 79 MSMEs are falling in sickness. Most of the studies found the less than 10percent MSMEs are accessing financial assistance. The Government and Financial Institutions should encourage the MSMEs which is very useful their survival of MSMEs. The Reserve Bank of India needs to encourage Banks to grant loans immediate direct to MSMEs sector these initiatives which are very helpful for their growth and survival in our country.

\section{References:}

1. Dr.Ashok Kumar Panigrahi (2012): "Risk Management in Micro, Small and Medium Enterprises (MSMEs) In India: A Critical Appraisal", Asia Pacific Journal of Marketing and Management Review, Volume 1(4), December 2012, ISSN 2319-2836.

2. Dr.Sultan Singh Jaswal ( 2014):" Problems and Prospects of Micro, Small and Medium Enterprises (MSMEs in India)", International Journal of Innovative Research and Studies (IJIRS), ISSN 2319-9725, Volume 3 Issue 5, may 2014.

3. Nishanth.P\& Dr.Jakkariya .K.A(2014: “ Barriers faced by Micro, Small and Medium Enterprises in Raising Finance", Abhinav National Monthly Referred Journal of Research in Commerce and Management, Volume 3, Issue 5 May 2014, ISSN 2277-1166.

4. Dr A. Shiralashetti: "Prospects and Problems of MSMEs in India - A Study ', Shiv Shakti, International Journal of Multidisciplinary and Academic Research (SSIJMAR), Volume.1, JulyAugust, ISSN 2278-5973.

5. Prof. M. Chandraiah\&R.Vani (2014): "The Prospects and Problems of MSMEs sector in India an Analytical Study", International Journal of Business and Management Invention, ISSN 23198028.

6. Report of Prime Minister task force on Micro Small and Medium Enterprises, Government of India, January 2010.

7. www.msme.gov.in 
8. www.dcmse.gov.in

9. www.nceuis.nic.in

10. www.business.gov.in.

11. www.smeworld.in

12. www.rbi.in

13. www.sidbi.in 